DOI: https://doi.org/10.32839/2304-5809/2021-4-92-65

УДК 338.22.021.4

Литвин О.Є., Падун А.О., Тищенко А.В.

Навчально-науковий інститут банківських технологій та бізнесу «Університет банківської справи»

\title{
ЕКОНОМІКА ПРОВІДНИХ КРАЇН СВІТУ В УМОВАХ ПАНДЕМІЇ COVID-19
}

\begin{abstract}
Анотація. У даній статті автори описують економічну складову суспільної кризи, що виникла у наслідок неочікуваного виявлення та стрімкого розвитку новітньої вірусної інфекції. «Коронакриза» являеться проблемою світового масштабу, яка не має дієвого шляху подолання, що обумовило актуальність даного дослідження. У статті висвітлено наслідки карантинних обмежень через пандемію COVID-19 для Китаю, США та країн Європи: Німеччини, Франції та Великої Британії. Проаналізовано дані за 2020 р. та висунуто припущення й прогнози на 2021 р., щодо впливу карантину та локдауну на економіку країн.
\end{abstract}

Ключові слова: ВВП, криза, економіка, карантинні обмеження.

Lytvyn Olena, Padun Anna, Tishchenko Anastasia Banking University

\section{THE ECONOMY OF THE WORLD LEADING COUNTRIES IN THE CONTEXT OF COVID-19}

Summary. This article describes the economic component of a social crisis that has arisen as a result of the unexpected discovery and rapid development of the latest viral infection. "Corona crisis" was a global problem that had no effective way to overcome, that determined the relevance of the study. The consequences of quarantine restrictions are highlighted due to the COVID-19 pandemic for China, the United States and European countries, such as: Germany, France and the United Kingdom. The data are analyzed for 2020; assumptions and forecasts are made for 2021 concerning the impact of quarantine and lockdown on the economy of the countries. The authors chose GDP indicator to illustrate the changes in the economic situation. There was a sharp decline in each country, which was a record, ahead of the global economic crisis in 2008 . In 2020 China's economy fell by $6.8 \%$ despite its stability the previous years. The United States experienced a deeper decline $-9.5 \%$, Germany $-10.1 \%$, France $-13.8 \%$. The record holder was the United Kingdom among all the countries with GDP decline by as much as $20.4 \%$ year on year. The reason for this decline was the introduction of strict quarantine, which significantly affected almost all sectors of the economy. The unemployment was rising worldwide, which could lead to a record number of people living below the poverty line. The decline in business activity had led to an increase in government spending on subsidies to households and businesses. However, the most crisis period had already passed and the economy gradually began to recover. Thus, the French government forecasted GDP growth of $7.4 \%$ in 2021 , the UK it had already grown by $15.5 \%$ in the 3rd quarter of 2020 but later slowed to $1.1 \%$. The United States received 3.5\% increase instead of expected $7 \%$. Thus, although the economic situation has not started to improve as fast as forecasted, a further downturn in the economy was not expected. However, the sharp resurgence in global COVID-19 cases showed that there were still obstacles to be navigated on the path to normality and that clear downside risks to activity would persist in the near term. Even if higher COVID-19 cases crimped future growth, the lockdown-induced contractions might not be as severe as initially feared. Aside from the speed at which restrictions on activity were eased in 2021 and the permanence of the rollback, the next greatest uncertainty was how household spending would respond in 2022. Whereas many economists suggested a fast unwind could lead to a surge in inflation, in our opinion, the vast bulk of excess savings would not be spent quickly.

Keywords: GDP, crisis, economy, quarantine restrictions.

П остановка проблеми. На початку грудня 2019 р. в лікарні китайського міста Уханя почали надходити хворі з симптомами вірусної пневмонії. Як наслідок, з 23 січня 2020 р. Китай закривае в'їзди та виїзди з країни, впроваджуе жорсткий карантин та зупиняе велике виробництво. Далі все більше країн оголошувало про нових інфікованих паціентів, закриття кордонів i впровадження карантину із жорсткими заходами. Все згадане вище стало великим потрясінням, особливо для економіки та медичної системи як окремих країн, так і усього світу загалом.

Аналіз останніх досліджень і публікацій. Вивченням наслідків карантинних обмежень та подальших прогнозів займаються як окремі журналісти та урядовці, так і міжнародні спілки й організації. Аналіз усіх джерел свідчить про те, що у всіх країнах, що були розглянуті, відбулися схожі сценарії розвитку подій в економіці.
Виділення не вирішених раніше частин загальної проблеми. Не дивлячись на наявність досліджень у џьому напрямку, досі не було зроблено спроби чіткої систематизації економічної складової суспільної кризи та впливу карантинних обмежень й локдауну на економіку розвинутих країн через пандемію COVID-19.

Метою статті e висвітлення, порівняння та аналіз проблем світової економіки під час пандемії та наслідків жорстких карантинних обмежень.

Виклад основного матеріалу. Зростання ВВП е сукупною вартістю всього виробленого на певній території за певний проміжок часу (як правило, за рік). Так як світове населення постійно зростає, то зростають потреби людей i обсяги виробництва. У деяких країнах поліпшуеться рівень життя: люди стають багатшими і споживають більше товарів (що теж призводить до зростання ВВП). А от його падіння свідчить 
“Молодий вчений» • № 4 (92) • квітень, 2021 р.

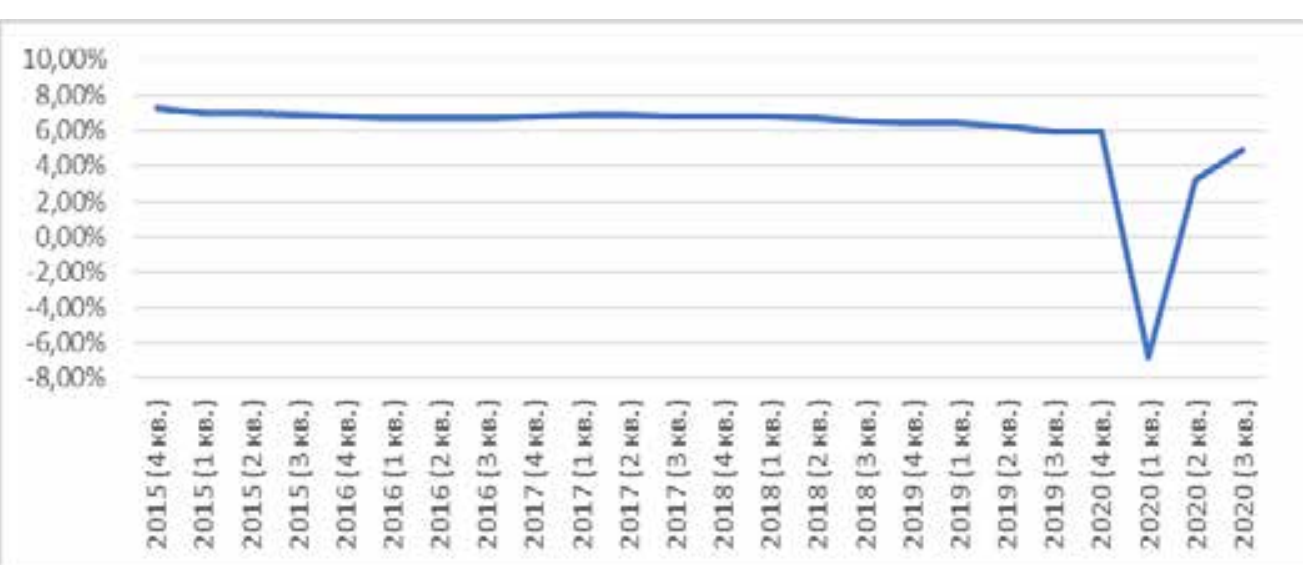

Рис. 1. Щоквартальні зміни ВВП Китаю, Q2 2020 р.

Джерело: складено авторами на основі [2]

про те, що економіка вже бореться із певними проблемами.

Варто зазначити, що Китай першим з провідних країн світу прийняв удар COVID-19 і об'явив про карантинні обмеження, відзвітувавши про перші економічні наслідки. Економіка країни впала на $6,8 \%$ у річному обсязі, тоді як майже півстоліття вона навіть не натякала про падіння і стрімко зростала до 15\% на рік [1].

Графрік, де можна побачити різке скорочення ВВП Китаю у першому кварталі 2020 року, зображений на рисунку 1 . Цей показник $є$ дуже низьким і дорівнюе -6,8\% [2].

Ще на початку «коронакризи» продажі авто у Китаї скоротилися на 92\% (це найбільший ринок збуту автомобілів у світі). Прибутки китайських компаній обвалилися на 38\%, що є максимальним показником за останні кілька десятиліть [3]. За даними Статистичного відомства Пекіну, промислове виробництво в Китаї у січні та лютому 2020 р. скоротилося на 13,5\%. Загальний оборот роздрібної торгівлі впав на 20,5\%. Для світу ці показники мають велику роль, адже Китай - це 17\% світової економіки [1].

На нашу думку, спад економіки в Китаї обіцяє проблеми розвинутим країнам, а країнам, що розвиваються і взагалі загрожуе катастрофою. Адже більшість 3 них залежать від залучення іноземного капіталу.

За даними Всесвітньої асоціащії фрінансистів, 3 початку 2020 р., коли стали очевидними масштаби епідемії в Китаї, відтік грошей з ринків, що розвиваються становив 100 млрд. доларів і набагато перевищив виведення капіталу навіть на піку фрінансової кризи 10-річної давнини.

На нашу думку, вивід західних грошей загрожуе країні девальвацію, падінням рівня життя, збільшенням витрат на обслуговування державних боргів та складністю із залученням нових. Оскільки постійно зростають величезні витрати на боротьбу з епідемією COVID-19, доходи скорочуються, бізнес та населення бідніють, експортні товари, сировина та комплектуючі дешевшають.

Таким чином, тільки за місяць 3 початку карантину у США про своє безробіття сповістили близько 22 млн. людей - кожен 8 працездатний американець. Це найбільша кількість безробітних у США за всю історію офіційних спостережень Американської службби праці (з 1960-х років).
Варто зазначити, що зростання безробіття спостерігається в усьому світі і може призвести до зростання рекордної кількості людей, що живуть за межею бідності - до 500 млн. чоловік. На жаль, ріст кількості інфікованих COVID-19 матиме негативний вплив на найбілыші економіки країн світу у середньостроковій перспективі. За даними Goldman Sachs, ріст ВВП США становитиме у першому кварталі 2021 р. лише 3,5\% з очікуваних 7\%.

У першому кварталі 2020 р. ВВП США скоротився на $4,8 \%$ у річному вираженні. Через пандемію коронавірусу економіка США у другому кварталі 2020 р. пережила небувалий обвал ВВП.

Графрік зміни приросту ВВП США до третього кварталу 2020 року зображений на рисунку 2. Як видно з графріку, спад ВВП був у 2008-2010 рр. через світову кризу. Але ще глибший спад ВВП спостерігався у 2020 р., починаючи з першого кварталу.

Скорочення доходів через падіння ділової активності посилюеться одночасним збільшенням витрат. США вже виділили майже 3 трлн. доларів на боротьбу з COVID-19 та на підтримку постраждалого від карантинних обмежень бізнесу і населення. На нашу думку, США доведеться наростити дефіцит бюджету і активно позичати кошти.

Більшість країн Свропи були змушені також піднімати економіку після введення карантину. Німеччина ввела карантинні обмеження 322 березня 2020 р., що мало свої наслідки для економіки країни. За даними Федерального статистичного управління Німеччини, ВВП країни у першому кварталі 2020 р. скоротився на 2,2\% порівняно 3 попереднім кварталом. Це був найбільш різкий спад після світової фрінансової кризи 2008 р. і другий за величиною після возз'єднання Німеччини.

Карантинні обмеження та локдан зумовили скорочення споживчих витрат на $3,2 \%$ та інвестиції компаній у заводи та обладнання на $6,9 \%$, зниження експорту на $3,1 \%$ та імпорту - на $1,6 \%$ [4].

За даними Міністерства економіки та енергетики ФРН, економіка країни з березня 2020 р. перебуває в глибокій рецесії. За оцінкою міністерства, навіть при умові пом'якшення обмежувальних заходів ситуація в країні залишиться несприятливою і буде поліпшуватися поступово. ВВП Німеччини у другому кварталі (з квітня по липень) 2020 р. скоротився на 10,1\% порівняно з попереднім кварталом. 


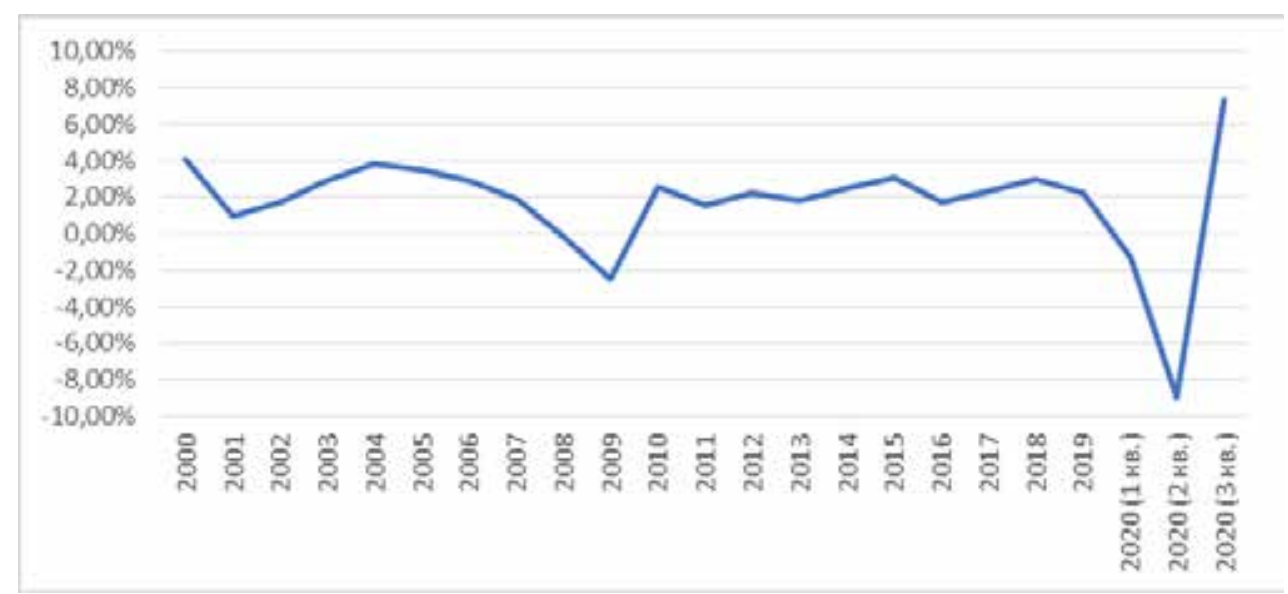

Рис. 2. ВВП США, 2000-2020 pp.

Джерело: складено авторами на основі [2]

Графік приросту ВВП Німеччини до третього кварталу 2020 року зображений на рисунку 3. Різкий спад ВВП спостерігався у 2008-2010 pр., проте у 2020 р., він був набагато критичний [2].

Помітно скоротився експорт та імпорт товарів і послуг, споживчі витрати громадян, а також інвестищії підприемств в обладнання $[5,6]$.

У другому кварталі 2020 р. ряд німецьких компаній опублікували піврічні звіти, зафіксувавши при цьому величезні збитки. Залізничний концерн «Deutsche Bahn» показав найбільший збиток у своїй історії, який становив 3,7 млрд. євро. Збитки автомобільного концерну «Volkswagen» складали 1,4 млрд. євро [7].

Уряд Франції ввів карантинні обмеження на п'ять днів раніше, ніж Німеччина - 17 березня 2020 p. За даними статистичного агентства INSEE Франції, ВВП країни скоротилося на рекордні 13,8\% у другому кварталі 2020 р., причиною якого стали незворотні наслідки пандемії COVID-19. Саме на цей період припадає значна частина суворих карантинних заходів, що вплинули на 12 мільйонів пращівників. У першому кварталі 2020 р. падіння економіки Франції становило 5,9\%, що є рекордним з 1949 р.
За даними INSEE, ВВП Франції у цілому скоротився на $19 \%$, порівняно з аналогічним періодом минулого року.

Графік приросту ВВП Франції до третього кварталу 2020 року зображений на рисунку 4. Як видно з графіку, спад ВВП спостерігався у 2008-2010 рр. під час світової кризи, але ще глибший спад був у 2020 р. [2].

Споживання домогосподарств скоротилося на $11 \%$ після падіння на 5,8\% у першому кварталі 2020 р. Формування основного капіталу скоротилося на $17,8 \%$ порівняно з зниженням на $10,3 \%$ у січні-березні 2020 р. Експорт Франції скоротився на 25,5\% після падіння на $6,1 \%$ у першому кварталі 2020 р. Імпорт скоротився на 17,3\% після зниження на $5,5 \%$ у першому кварталі 2020 р. [8].

Уряд Франції у свою чергу прогнозуе падіння ВВП на $11 \%$, а також рекордний дефіцит бюджету, що може становити $11,4 \%$ [8]. За прогнозами Європейської комісії, падіння економіки Франції мае спостерігатися на рівні $8,2 \%$, а зростання у 2021 р. - на $7,4 \%$.

Проте не тільки Франція зазнала нищівних наслідків пандемії, разом з нею чемпіоном по падінню економіки стала країна 3 дуже жорстко орга-

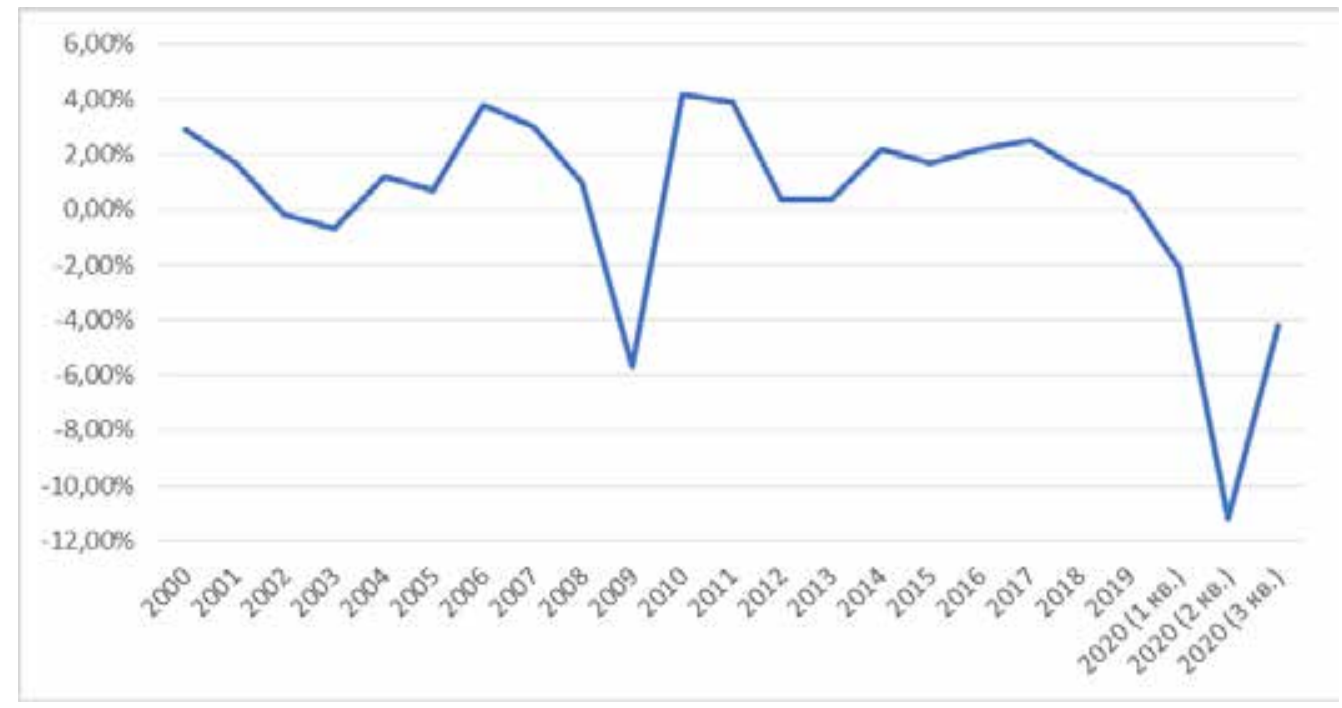

Рис. 3. ВВП Німеччини, 2000-2020 рр. 


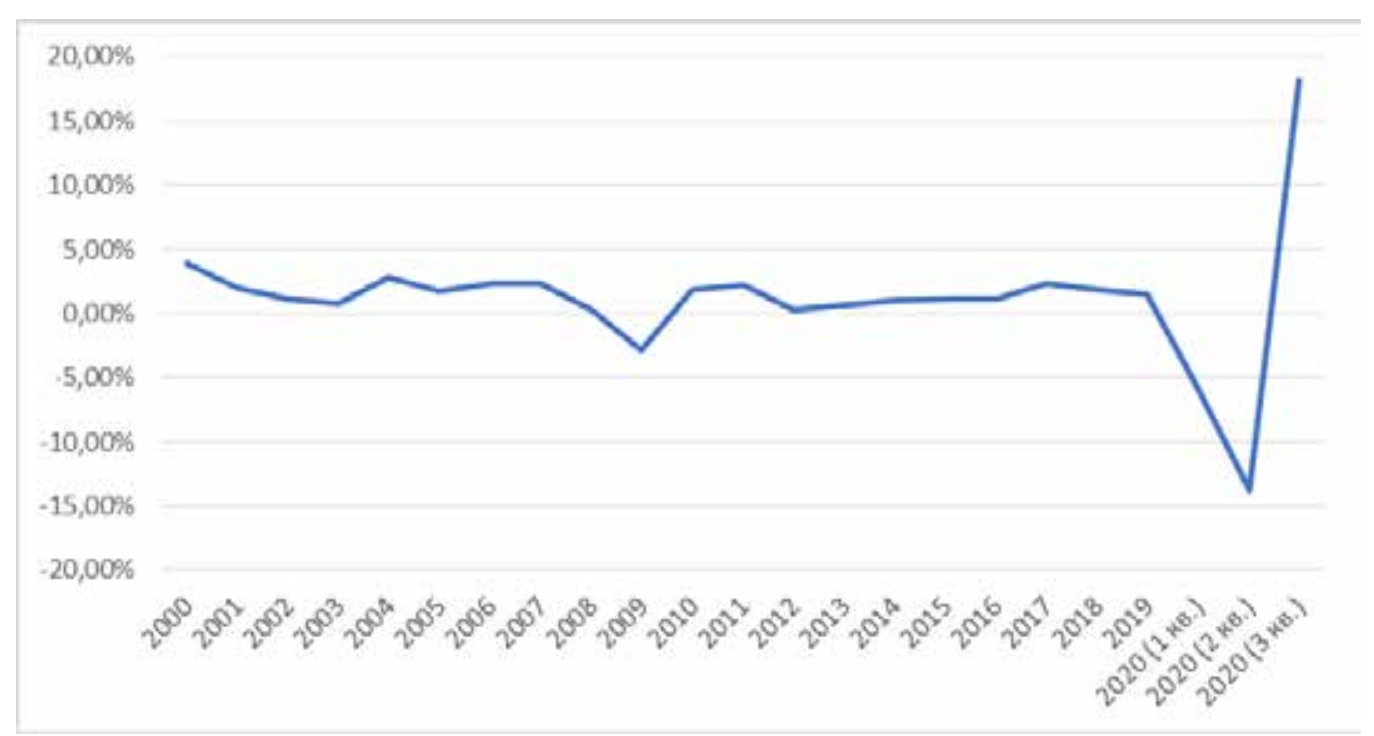

Рис. 4. ВВП Франції, 2000-2020 рр.

Джерело: складено авторали на основі [2]

нізованим локдауном - Великобританія. Падіння економіки цієї країни у другому кварталі 2020 р. стало рекордним серед найбільших і найважливіших економік світу. Падіння ВВП становило 20,4\%, порівняно 3 -2,2\% за підсумками першого кварталу 2020 р. [9]. Показники також свідчать про те, що економіка скоротилася на 24,5\%.

За даними Управління Національної Статистики (ONS), після двох кварталів скорочень підряд, ВВП Великобританії зросло на рекордні 15,5\% за третій квартал (з липня по вересень) 2020 р. Це найбільший квартальний ріст економіки Великобританії з 1955 р.

Однак, варто зазначити, що це - наслідок подальшого послаблення обмежень блокування у третьому кварталі 2020 р., а також часткове відновлення активності у квітні 2020 р. Проте, рівень ВВП у Великобританії все ще на 9,7\% нижчий, ніж до пандемії кінця 2019 р. [10].

Щомісячні показники ВВП у 3 кварталі 2020 року свідчать про те, що в серпні та вересні спостерігалося уповільнення темпів зростання, оскільки протягом кварталу динаміка зменшувалася. У липні 2020 р. ВВП збільшився на 6,3\%, завдяки послугам на розміщення та харчування, оскільки обмеження на ізоляцію були зняті. У липні 2020 р. також збільшилася активність в житловому будівництві, а відкриття автосалонів сприяло зростанню оптової та роздрібної торгівлі й ремонту автомобілів [10].

У вересні ВВП сповільнився - до 1,1\%, де професійна, наукова та технічна діяльність внесли найбільший вклад, а юридична діяльність, бухгалтерський облік та реклама показали сильне зростання після серпня 2020 р. Освіта мала великий позитивний внесок у вересні 2020 р., оскільки школи домоглися подальшого прогресу в поверненні до рівня викладання, аналогічного тому, який був до закриття 23 березня 2020 р., в основному за рахунок збільшення відвідуваності учнями [10].

Графрік зміни реального ВВП Великої Британії зображений на рисунку 5. Різкий спад ВВП, як видно на графріку, вже спостерігався у першому кварталі 2020 р. [2].

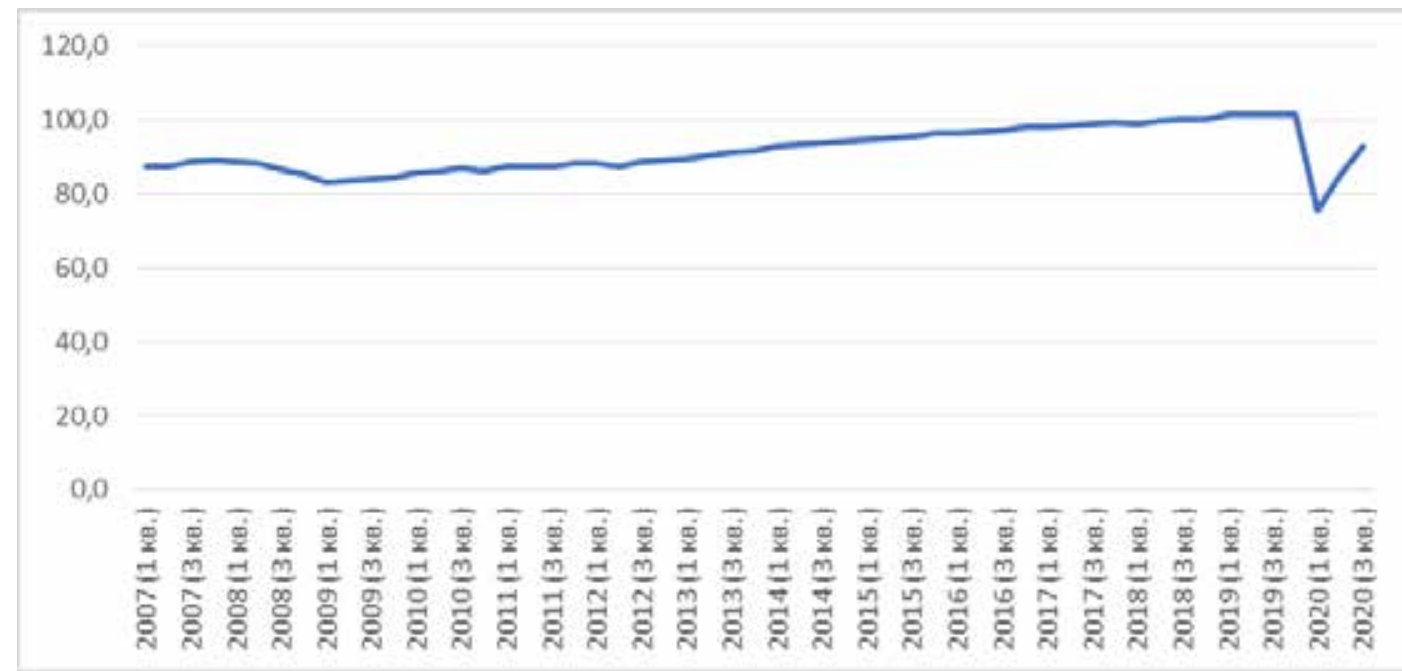

Рис. 5. ВВП Великобританії, 2007-2020 pp.

Джерело: складено авторами на основі [2] 
У третьому кварталі (з липня по вересень) 2020 р. відбулося рекордне зростання обсягів послуг, виробництва і будівництва, завдяки ослабленню обмежень у другому кварталі. Обсяг послуг виріс на 14,2\%, обсяг виробництва - на 14,3\%, а обсяг будівництва збільшився на 41,7\%. Однак, рівні виробництва у цих галузях залишилися найнижчими за ті, які спостерігалися до пандемії [10].

Після рекордних скорочень у 2 кварталі (3 квітня по червень) 2020 р. у 3 кварталі (з липня по вересень) 2020 р. відбулося значне зростання приватного державного споживання, валового накопичення капіталу та імпорту. Однак, рівень витрат залишився значно нижчим, на відміну від рівня, що спостерігався на початку 2020 р. до пандемії, оскільки зростання інвестищій у бізнесі було набагато слабкіше, ніж у приватному споживанні [10].

Висновки і пропозиції. Наслідки карантинних обмежень мають великий негативний вплив на економіку провідних країн світу. Перш за все, це виявилося у значному скороченні ВВП та зниженні рівня зайнятості. На даний час розвинуті країни оговтуються від неочікуваного спаду економіки та роблять все можливе для їі відновлення. Пандемія COVID-19 похитнула економіку навіть стабільно розвинутих країн з міщною економічною системою.

Отже, уряди розвинутих країн мають без обмежень підтримувати постраждалі від пандемії коронавірусу підприемства та послабити бюджетні правила.

Поступове зменшення захворюваності на COVID-19 у розвинутих країнах показало, що все ще існують перешкоди і явні негативні ризики для світової економіки, які будуть зберігатися у найближчі роки. Багато економістів припускають, що швидке подолання кризи, пов'язане з COVID-19, може призвести до сплеску інфрляції у світі. Але на нашу думку, переважна частина надлишкових заощаджень у розвинутих країнах не буде витрачена досить швидко.

\section{Список літератури:}

1. Коронавирус обрушил экономику Китая. На очереди - остальной мир. URL: https://www.bbc.com/russian/ news-52319211

2. ВВП стран мира. URL: https://ru.investing.com/search/?q=ввп\%20стран

3. Lytvyn O., Gorkavenko M. Prospects of Innovative Development and Cooperation Between China and Ukraine // NEW ECONOMICS : матеріали Міжнародного наукового фборулу "NEW ECONOMICS - 2020». (м. Київ, 31 жовтня 2020 р.); Асоціація сприяння глобалізації освіти та науки «СПЕЙСТАЙМ». Київ, 2020. С. 98-100.

4. Економіка Німеччини впала в рецесію. URL: https://www.epravda.com.ua/news/2020/05/25/660918/

5. Литвин O.Є. Глобалізаційні виклики та їхній вплив на сталий розвиток економіки // Механізми забезпечення ефективності та конкурентоспроможності банківської системи та економіки України : монографрія / за заг. ред. д.е.н. Г.Т. Карчевої. Київ : ДВНЗ «Університет банківської справи», 2019. С. 36-45.

6. Tetiana Bulakh, Yuliia Rusina, Alla Koval, Olena Lytvyn, Olena Budiakova. Modeling of the functional dependence of VAT tax liabilities on input VAT for the enterprises. International Journal of Scientific \& Technology Research. Vol. 9. Issue 3, March 2020. Edition - ISSN 2277-8616. P. 5881-5886.

7. Экономика Германии обвалилась до рекордных за 50 лет показателей. URL: https://biz.liga.net/ekonomika/ all/novosti/ekonomika-germanii-vo-ii-kvartale-obvalilas-do-rekordnyh-za-50-let-pokazateley

8. Економіка Франції скоротилася на рекордні з післявоєнного часу 13,8\%. URL: https://www.epravda.com.ua/ news/2020/07/31/663575/

9. «Эра коронавируса: «рекорды» Великобритании, новый 1968-й во Франции и локдаун по-шведски». URL: https://m.business-gazeta.ru/blog/478572

10. GDP first quarterly estimate, UK: July to September 2020. URL: https://www.ons.gov.uk/economy/ grossdomesticproductgdp/bulletins/gdpfirstquarterlyestimateuk/latest\#headline-gdp

\section{References:}

1. Koronavyrus obrushyl ekonomyku Kytaia. Na ocheredy - ostalnoi myr [Coronavirus has brought down the Chinese economy. The rest of the world is next]. URL: https://www.bbc.com/russian/news-52319211

2. VVP stran myra [GDP of the countries of the world]. URL: https://ru.investing.com/search/?q=ввп\%20стран

3. Lytvyn O., Gorkavenko M. (2020). Prospects of Innovative Development and Cooperation Between China and Ukraine // NEW ECONOMICS: materialy Mizhnarodnoho naukovoho forumu «NEW ECONOMICS - 2020» (m. Kyiv, 31 zhovtnia 2020 r.); Asotsiatsiia spryiannia hlobalizatsii osvity ta nauky «SPEISTAIM». Kyiv, pp. 98-100.

4. Ekonomika Nimechchyny vpala $v$ retsesiiu [The German economy has fallen into recession]. URL: https://www.epravda.com.ua/news/2020/05/25/660918/

5. Lytvyn O.Ye. (2019). Hlobalizatsiini vyklyky ta yikhnii vplyv na stalyi rozvytok ekonomiky // Mekhanizmy zabezpechennia efektyvnosti ta konkurentospromozhnosti bankivskoi systemy ta ekonomiky Ukrainy [Globalization challenges and their impact on sustainable economic development // Mechanisms for ensuring the efficiency and competitiveness of the banking system and the economy of Ukraine]: monohrafiia / za zah. red. d.e.n. H.T. Karchevoi. Kyiv: DVNZ «Universytet bankivskoi spravy», pp. 36-45.

6. Tetiana Bulakh, Yuliia Rusina, Alla Koval, Olena Lytvyn, Olena Budiakova (2020). Modeling of the functional dependence of VAT tax liabilities on input VAT for the enterprises. International Journal of Scientific \& Technology Research, vol. 9, issue 3, March 2020. Edition - ISSN 2277-8616. Pp. 5881-5886.

7. Ekonomika Hermanyy obvalylas do rekordnykh za 50 let pokazatelei [The German economy collapsed to a record level in 50 years]. URL: https://biz.liga.net/ekonomika/all/novosti/ekonomika-germanii-vo-ii-kvartale-obvalilasdo-rekordnyh-za-50-let-pokazateley

8. Ekonomika Frantsii skorotylasia na rekordni z pisliavoiennoho chasu 13,8\% [The French economy has shrunk by a record 13.8\% since the postwar period]. URL: https://www.epravda.com.ua/news/2020/07/31/663575/

9. Era koronavyrusa: «rekordy» Velykobrytanyy, novyi 1968-y vo Frantsyy y lokdaun po-shvedsky [The era of coronavirus: UK "records", a new 1968 in France and a Swedish lockdown]. URL: https://m.business-gazeta.ru/blog/478572

10. GDP first quarterly estimate, UK: July to September 2020. URL: https://www.ons.gov.uk/economy/ grossdomesticproductgdp/bulletins/gdpfirstquarterlyestimateuk/latest\#headline-gdp 